\title{
Evita el Drama (Avoid Drama): A Multimodal Discourse Analysis of a XXI Century TV Advertisement
}

\author{
Lizzeth Sánchez-Solís \\ University of Guanajuato, MEXICO \\ Division of Social Sciences and Humanities
}

Received: 1 June 2020 • Accepted: 25 August 2020 - Published Online: 4 October 2020

\begin{abstract}
Throughout history, machismo has permeated in many different sectors of society. Sometimes it is almost imperceptible. For that reason, this multimodal discourse analysis combines features of a functional grammar model by Halliday and certain principles of critical discourse analysis to determine the construct of a washing powder TV advertisement launched in Mexico in 2018. The results show that advertisements tend to be sexist and promote machismo behaviors, gender violence and the normalization of those in a subtle way. Publicity is a source that plays an important role in shaping the reality of society.
\end{abstract}

Keywords: machismo, gender violence, sexist publicity, normalization.

\section{Introduction}

This paper is aimed to analyze a washing powder TV advertisement of the brand Ariel, which was launched in Mexico in 2018. The advertisement shows the roles of a typical family inside the household. However, machismo in the advertisement is easily observable. For that reason, I will start by providing a conceptual framework in which distinct terms will be defined, like machismo in Mexico, the stereotype of the Mexican mother as a domestic worker, and the normalization of machismo in TV advertisements. Later on, I will describe the methodology used to carry out this analysis, which is multimodal discourse analysis (MDA). It involves a Halliday's functional grammar model, some features of critical discourse analysis (CDA), and some principles to analyze visuals. Then the analysis will be conducted with the help of the mentioned tools, to finish with general thoughts about the role of this kind of publicity in Mexican society.

\subsection{Machismo in Mexico: A general overview}

In 1950, in his master piece El Laberinto de la Soledad, Octavio Paz portrays different aspects of the general conceptions of the Mexican woman and the macho. According to Paz, the Mexican woman has a cosmic and social significance: in her daily life, her function consists of making prevail law and order, pity and sweetness. She is the selfless mother. On the other hand, the author states that the Mexican macho is aggressive, impassible, invulnerable, violent, arbitrary, unpredictable, not a coward. In other words, he is power. Paz suggests that resentment is the basis of the macho's character. Machismo, then, could be defined as a belief in male 
superiority. Even when Paz's book was first published 70 years ago, the general conceptions of the Mexican woman and the macho still prevail in different sectors of society, in terms of seeing women as inferior to men.

- The analyzed advertisement promotes machismo behaviors and gender violence.

- The focus of the advertisement is not the product per se but an adolescent's behavior.

- Sexist publicity prevails on Mexican TV.

Lewis (1964) stated that the Mexican macho is the man who is dominant, brave, boasts many sexual exploits, has a complex of Don Juan. From his proud and vanity, he sees the woman as an inferior being, and enjoys humiliating and denigrating her. For him there is no more feeling, no more reason than his own. The macho thinks he is the one who must command and be obeyed (Lewis, 1964). While the Mexican woman, according to this author, should limit herself to be sweet and submissive to please the men (her father, brothers, boyfriends, husband, in general any men in her life). This vision of the roles of the Mexican macho and the Mexican woman indicates that the woman is seen merely as an object that is there to the service of the man, who is considered as the only one that matters. This situation is visible in different contexts in the Mexican society it is not limited to age, race or ethnicity, or socioeconomic status.

Taking into account the previously mentioned works and some others, Lugo (1985) defines machismo as a series of behaviors that exalt the virility, violence, the ostentation of sexual potency, the ability to drink alcohol, physical superiority, and the use of brute force. In general, machismo is the magnification of the masculine and the he contempt of the constitution, the personality and the essence of the feminine. In that regard, machismo is the reproduction of unfair power relations between man and woman.

A more recent definition of machismo in Mexico is the one provided by Moral and Ramos (2016). They define machismo as an ideology that defends and justifies the superiority and dominance of men over women; exalts masculine qualities, such as aggressiveness, independence, and dominance, while stigmatizes feminine qualities, such as weakness, dependency, and submission. This definition takes up the features addressed by other authors and concentrates them into a clear conceptualization of machismo.

\subsection{The stereotype of the Mexican mother as domestic worker}

Throughout the world history, women have been in charge of the domestic chores, work for which they are not remunerated. The main reason why women are responsible for the domestic work at their homes is the gender differentiation (Pedrero, 2004). This means that historically, regardless socioeconomic class, age or generation, race or ethnicity, societies have assigned different roles for men and women in their daily lives based on their gender. But what is gender?

Sometimes the words sex and gender are confused and used interchangeably. Newman (2002) states that:

"sex" is defined as the biological status of a person as either male or female based on anatomical characteristics, whereas 'gender' is used to refer to socially constructed roles and cultural representations. "Gender role" refers to the socially ascribed characteristics and expectations: attitudes, behaviors, beliefs and values associated with being male or female in a particular culture. (p. 353)

This indicates that the specificities of what a woman and a man are supposed to do, to believe, and how they must behave depend on what society establishes. In this regard, Rendón 
(1997, as cited in Pedrero, 2004) indicates that the sexual division of job has been seen as something natural. It has always been there and cannot change without violating a social and almost immutable order. However, nowadays it has been considered that it is time to change that vision of gender roles.

Pedrero (2004) argues that social organization attributes women the responsibility of the domestic work. She also mentions that in the field of psychology, domestic work is associated with alignment, domination and subordination (by the woman, I would add). Here again it can be demonstrated how thanks to the role of women at home as domestic workers, and the features that this involves, the beliefs, behaviors and attitudes of machismo are reinforced. The main functions of domestic work are (Campillo, 2000; Pedrero, 2004):

- Providing housing: cleaning it, doing maintenance works, fix the house, furnish it, equip it, doing the paperwork in order to purchase or rent a house or an apartment, etc.

- Providing nutrition: planning the meals, getting the ingredients, prepare the meals, serve them, washing the dishes, etc.

- Providing clothing: doing the laundry, ironing, sewing, purchasing clothes or getting fabrics and confectioning clothes, etc.

- Taking care of: the kids, the sick, the elders, or any members of the family who require constant support.

- And some additional activities: transportation, shopping, planning and control of finances, among others.

Nowadays in Mexico, women are still mostly in charge of carrying out the majority of, if not all, these activities. Apart from that, some of them have extra domestic work. Meaning that they have works for which they are remunerated, plus what they do at home.

\subsection{The normalization of machismo in TV advertisements}

In this section, I will address the different ways in which women and men are represented on TV advertisements. As stated above, because of machismo, currently the Mexican woman is seen as inferior in relation to the man, and she is subordinated to him. This establishment of gender roles has been perpetuated by the societies of the world through generations and it is easily identifiable in almost every social context. An example of this is publicity. This paper focuses specifically on a TV advertisement.

Machismo has been present in publicity since decades ago, even before TV was a mainstream means of communication. It could be argued that advertisements follow the norms established by society. Advertising makes women the target of marketing strategies, because women are the conservator of values and the main agent of consumption, given their dual status as buyer of articles for their own use and for the use of others (Blanco, 2005). In Mexican TV advertisements, machismo can be noticeable throughout various characteristics that fit such norms. Ječmínková (2010) points out some features than can be observable in advertisements and that fall into machismo behaviors; for instance:

- the woman represents a 'good' mother and wife,

- but, at the same time, women are used as seductive characters,

- women appear overall in advertisements of feminine beauty or of household cleaning products,

- they also appear in advertisements of food products, not as a consumer but as the one who serves the others. 
In summary, the woman is understood as a maid, what depicts sexism in publicity (Ječmínková, 2010). All these aspects shown on TV advertisements contribute to the perpetuation and reinforcement of normalization of machismo in society.

However, the way in which women are represented in publicity is not the only factor influencing the normalization of machismo, but also the way men are portrayed. The representation of men on media shows that in general they have an aggressive attitude towards the others. This normalization of machismo and the aggressive attitude of men seen in publicity lead to the normalization of gender violence.

Gender violence is the product of the ideology of machismo. Expósito (2011) defines it as physical or psychological coercion exerted on a person to vitiate their will and force them to perform a certain act. In other words, in a gender violence scenario men tend to be the abusers, while women are the abused. This again is based on the idea of machismo that indicates that women men are superior to women.

The normalization of gender violence as on media as in real life contexts, is due to the social convention of machismo. Meaning that this is a cultural phenomenon that establishes that society accepts abusive behavior patterns without being aware of it (Expósito, 2011). This situation does not help people to develop their critical thinking and question the customs that have been passed down from generation to generation.

In this regard, TV plays a major role. Núñez (2005) states that the fact that the viewers do not question the gender stereotypes that constantly appear on TV shows and publicity depends on two main factors. The first one is that TV has made the audience to be used to interpreting from their own experience and environment instead of thinking critically. The second influencing factor is the relationship between the viewers' everyday lives and TV. Núnez points out that TV is the device that best reproduces the social reality, people and their situations. The author adds that the place TV occupies at the privacy at the homes or, in other words, at the inside of society, what makes TV one of the most powerful media. Then, it could be argued that TV is a highly influencing transmitter of messages which contributes to the prevalence of stereotypes, in this case, gender stereotypes.

\section{Methodology}

In this section, I will describe the methodology used to carry out this multimodal discourse analysis. As its name indicates, MDA entails various discourse analysis approaches. In this case, I will use a Halliday's functional grammar model to analyze the meanings through the language choices of the text. I will also make use of CDA in order to analyze the text and the interactions that reflect relations of power in it, and to analyze the visuals appearing in the commercial.

\subsection{Multimodal discourse analysis}

Multimodal discourse analysis is an approach to analyze either written or spoken discourse in relation to the semiotic elements around the discourse. MDA studies the use of language "in combination with other resources, such as images, scientific symbolism, gesture, action, music and sound" (O'Halloran, 2011: 1). Since this paper is an analysis of a TV advertisement, its text and the aspects surrounding it are not the only features to analyze, but also the visual elements of the advertisement. To that end, besides CDA, a MDA will be used.

Similar to CDA, MDA considers the context as a unit of analysis, known as well as situation type. First, it will be necessary to analyze the use of the language in terms of Halliday's 
functional grammar. This "means that priority is given to the view 'from above'; that is, grammar is seen as a resource for making meaning - it is a 'semantic' kind of grammar. But the focus of attention is still on the grammar itself" (Halliday \& Matthiessen, 2004: 31). Therefore, grammar has to be analyzed as the means to convey meaning.

Halliday (1978) developed a model to determine semantic features by semiotic elements, which could be adapted for carrying out a MDA. The model indicates:

The situation type is a semiotic construct which is structured in terms of field, tenor and mode: the text-generating activity, the role relationships of the participants, and the rhetorical modes they are adopting. These situational variables are related respectively to the ideational, interpersonal and textual components of the semantic system: meaning as content (the observer function of language), meaning as participation (the intruder function) and meaning as texture (the relevance function). (p. 125)

variables.

Table 1 explains the roles and relation of the semiotic construct and the situational

Table 1. Functional model of language

\begin{tabular}{ll}
\hline Feature of context & Function of language \\
\hline field: what the text is about & ideational metafunction \\
\hline tenor: the relationship between & interpersonal metafunction \\
speaker/writer and listener/reader & \\
\hline mode: how the text is constructed & textual metafunction \\
\hline
\end{tabular}

Note. Source: Ewing, 2001, p. 3.

Through the analysis of these elements it is possible to determine how the language choices (the use of particular vocabulary and specific grammatical features) of any text contribute to create meaning.

MDA contemplates different aspects to be analyzed in the conveying of meaning, known as levels of language. Those levels are the purpose of the text, which depends on each particular situation; the semantic level (meaning), the lexicogrammatical level (words and structure), and the graphophonic level (sounds and symbols) (Ewing, 2001). In summary, MDA takes into account as units of analysis the language choices in a text, the meaning of the text and its impact on the interlocutors, as well as the semiotic features that appear along the message. Since this paper is aimed to analyze a TV commercial, the features to analyze visual semiotics will be discussed in the next section.

\subsection{Critical discourse analysis}

Critical discourse analysis (CDA) is a way of analyzing either written or spoken texts and their impact on society, from a sociopolitical stance. The aim of CDA is to display how language is used to establish power and dominance of some social groups over others. In accordance to van Dijk (1993):

Power involves control, namely by (members of) one group over (those o) other groups. Such control may pertain to action and cognition: that is, a powerful group may limit the freedom of action of other, but also influence their minds. Besides the elementary recourse to force to directly control action (as in police violence against demonstrators, or male violence against women), 'modern' and often more effective power is mostly cognitive, and enacted by persuasion, dissimulation or manipulation, among other strategic ways to change the mind of others in one's own interests. (p. 254) 
The power that certain groups exercise over others takes many different forms. It implies influencing on the way certain individuals act or think. In addition to power, there is the dominance factor. Dominance is "the exercise of social power by elites, institutions or groups, that results in social inequality, including political, cultural, class, ethnic, racial and gender inequality" (van Dijk, 1993: 249-250). According to van Dijk (1993), the main difference between power and dominance is that, unlike power, dominance "may be enacted and reproduced by subtle, routine, everyday forms of text and talk that appear 'natural' and quite 'acceptable"' (p. 254). What, in relation to this paper, happens through media and advertising. Van Leeuwen (2015) states that:

Critical discourse analysis (CDA) studies the role of text and talk in creating, maintaining, and legitimating inequality, injustice, and oppression in society. [It uses] an empirical and rational foundation for doing so. It seeks to promote awareness of this aspect of language use and to argue explicitly for change on the basis of its findings. (p. 1)

In this sense, it could be implied that CDA seeks to demonstrate social inequality promoted by the most powerful groups in society. Wodak and Meyer (2011) argue that "particularly the language of the mass media is scrutinized as site of power" (p. 6). Thus, CDA turns in a suitable tool to analyze discourse used in media, in this case on TV.

Experts in the subject have suggested that in order to carry out a CDA, it is necessary to take into account different aspects. In the first place, that it is a multidisciplinary approach. Second, not only the language used in a text is analyzed, but also the context, and the relationships between the text and social cognition, the text and power, the text and society and culture, and the role of the text in constructing power relations in society (van Dijk, 1993; van Leeuwen, 2015; Wodak \& Meyer, 2011). It is important to contemplate these elements because this way it would be possible to determine the role of a text in a specific group of the society.

\subsection{Visual semiotic analysis}

The visual semiotic features to analyze through this paper are the sequence that appears on screen, the characters and their actions. Bignell (1997) asserts that advertisements are designed to shape our perception of reality. The function of advertising goes beyond selling products, they also create structures of meaning (Williamson, 1978, as cited in Bignell, 1997). In other words, advertisements influence significantly on the way we experience the social world. The aim of advertisements is:

to engage us in their structure of meaning, to encourage us to participate by decoding their linguistic and visual signs and to enjoy this decoding activity. Ads make use of signs, codes, and social myths which are already in circulation, and ask us to recognize and often to enjoy them. (Bignell, 1997: 33)

By means of publicity, companies show us an 'ideal' world and create us an internal and unconscious desire to live a life similarly to what is portrayed in advertisements, so that we feel we are able to belong to that 'ideal' world. This way, some behaviors as machismo and the relations of power are perpetuated without the audience even noticing it.

Another semiotic aspect that is relevant in the analysis of visual advertisements is the gestures used in the TV advertisement as a source to deliver a message. Kendon (2013) sees gestures as actions performed with the body that may or not come along with verbal expressions as part of the discourse in order to convey meanings. The author adds that gestures can be used to extend, enrich, supplement, or complement spoken utterances; and that the meanings of gestures are generally governed by social conventions. 


\section{Discussion of findings}

The advertisement to be analyzed next is a TV commercial launched in Mexico in 2018. The product advertised in the commercial is washing powder. The brand is Ariel. The commercial will be analyzed under the parameters of MDA. I will analyze the dialogue based on Halliday's model of functional grammar and from a CDA perspective. Later on, I will analyze the semiotic features, meaning the visuals and gestures.

\subsection{Description of the TV advertisement}

In this section, I will provide two brief descriptions, one of the advertisement and another one of the context in which the advertisement was launched:

- The scenario: It can be seen that the advertisement takes place at a home.

It seems to be the house of a middle-social class family.

- The characters are a 40-year-old (approx.) mother and a 17-year-old (approx.) male adolescent.

- The actions taking place in the advertisement: the mother carries out the domestic work, while the son gets dress.

The commercial was launched in Mexico in 2018. Based on what previously discussed about publicity directed to women, it could be argued that the advertisement is targeted to Mexican housewives.

\subsection{Analysis of the dialogue}

I will analyze the dialogue using a MDA methodology. I will take into account Halliday's model of functional grammar in combination with a CDA perspective. The dialogues will be presented in Spanish as they are in the original advertisement, together with a translation into English. Table 2 shows the advertisement's situation type:

Table 2. Advertisement's situation type

\begin{tabular}{|c|c|c|c|}
\hline Feature of context & \multicolumn{3}{|c|}{ The dialogue as the text } \\
\hline field & \multicolumn{3}{|c|}{$\begin{array}{l}\text { a male adolescent complains to his mother for } \\
\text { not having washed his shirt }\end{array}$} \\
\hline tenor & \multicolumn{3}{|c|}{$\begin{array}{l}\text { inside the advertisement: mother and son } \\
\text { outside the advertisement: seller and customer }\end{array}$} \\
\hline \multirow{6}{*}{ mode } & \multicolumn{3}{|c|}{15 explicit verbs +1 implicit $=16$ verbs } \\
\hline & Mood & Verbs used & $\%$ \\
\hline & Declarative & 14 & $87.5 \%$ \\
\hline & Imperative & 1 & $6.25 \%$ \\
\hline & Interrogative & 1 & $6.25 \%$ \\
\hline & Total & 16 & $100 \%$ \\
\hline
\end{tabular}

The field describes the general situation taking place in the advertisement: a family's common routine inside the household. The tenor indicates the relationship of the characters, meaning mother and son; as well as the relationship between the interlocutors in the social context which are the company and the audience. In this case it could be implied that the speaker is the washing powder company and the listener are Mexican housewives. The $87.5 \%$ of the verbs used are in declarative mode. This shows that most of the statements used are facts. Apparently, there is no opportunity to question the message. Tables 3, 4 and 5 specify the ideational meaning of the text. 
Table 3. Verbs used in the text

\begin{tabular}{lcccc}
\hline & \multicolumn{2}{c}{ by the mother } & \multicolumn{2}{c}{ by the son } \\
\hline person & times used & $\%$ & times used & $\%$ \\
\hline $1^{\text {st }}$ & 1 & $6.25 \%$ & 3 & $18.75 \%$ \\
\hline $2^{\text {nd }}$ & - & - & 1 & $6.25 \%$ \\
\multirow{2}{*}{$3^{\text {rd }}$} & 8 & $50 \%$ & 3 & \multirow{2}{*}{$18.75 \%$} \\
\hline \multicolumn{4}{c}{ Total of verbs 16 (100\%) } \\
\hline
\end{tabular}

In total the actors in the advertisement use 16 verbs, 9 by the mother and 7 by the son. The mother utters $56.25 \%$ of the total of verbs, while the son utters $43.75 \%$. This means that the interaction between the participants is sort of balanced. However, the mother is the character who uses the higher number of verbs.

Table 4. Verbs used by the mother

\begin{tabular}{cccc}
\hline person & subject & times each subject was used & \% each subject was used \\
\hline $1^{\text {st }}$ sing & herself & 1 & $11.11 \%$ \\
\hline $2^{\text {nd }}$ sing & - & - & - \\
\hline \multirow{3}{*}{$3^{r d} \operatorname{sing}$} & her son & 5 & $55.55 \%$ \\
\cline { 2 - 4 } & washing powder & 2 & $22.22 \%$ \\
\hline $1^{\text {st }} p l$ & - & - & - \\
\hline $2^{\text {nd }} p l$ & - & - & - \\
\hline $3^{r d} p l$ & dramas & 1 & $11.11 \%$ \\
\hline & Total & 9 & $99.99 \%$
\end{tabular}

This table focuses on the total of verbs uttered by the mother. The mother makes use of the first person only once, what represents the $11.11 \%$ of the total of subjects mentioned, against the $88.88 \%$ of times that she utilizes the third person in singular. From the eight times she uses the third person, in five the subject is her son, more than the half of the total of subjects uttered.

Table 5 . Total of verbs used by the son

\begin{tabular}{lccc}
\hline \multicolumn{1}{c}{ person } & subject & times each subject was used & \% each subject was used \\
\hline $1^{\text {st }}$ sing & himself & 3 & $42.85 \%$ \\
\hline $2^{\text {nd }}$ sing & his mother & 1 & $14.28 \%$ \\
\hline $3^{\text {rd }}$ sing & shirt & 2 & $28.57 \% \%$ \\
\hline $1^{\text {st }} p l$ & - & - & - \\
\hline $2^{\text {nd }} p l$ & - & - & - \\
\hline $3^{\text {rd }} p l$ & girls & 1 & $14.28 \% \%$ \\
\hline & Total & 7 & $99.98 \%$ \\
\hline
\end{tabular}

Regarding the sons' interventions in the advertisement, the person that he uses more times is the first person in singular.

The analysis of these data shows that the focus of the utterances expressed along the advertisement is the son rather than the washing powder. This coincides with what explained by Bignell (1997), being that the center of attention in advertisements are nor precisely the products, but other features appearing on the screen. What companies sell are not the products per se, but 
ideas of a wanted lifestyle. This functional grammar analysis demonstrates the marketing strategy discussed above about publicity conceiving women as the buyers of products for serving others.

Now, I will analyze the utterances of the text from a CDA stance, through a table in which I will include the original utterance in Spanish, a translation into English and the critical analysis. The utterances said by the mother will include at the beginning a "M", while the ones by the son, a "S:" for English and a "H" for Spanish.

Table 6. A CDA of the utterances of the advertisement

\begin{tabular}{|c|c|}
\hline & Translation into English \\
\hline 1. & $\begin{array}{cc}\text { M: Mi hijo cambia de novia como de calzones. } & \begin{array}{l}\text { M: My son changes girlfriend as he does with } \\
\text { his knickers. }\end{array}\end{array}$ \\
\hline CDA & $\begin{array}{l}\text { Comparison of women with knickers portrays women objectification. It is necessary to } \\
\text { highlight that the pragmatic use of the word "calzones" in Mexico has to do with things which } \\
\text { have a low value. }\end{array}$ \\
\hline 2. & M: Se cree todo un galán. $\quad$ M: He sees himself as a ladies' man. \\
\hline CDA & $\begin{array}{l}\text { This indicates that the man who 'has' many women is admired = He is supposed to have some } \\
\text { characteristics of what is understood in Mexico as a macho }\end{array}$ \\
\hline 3. & $\begin{array}{ll}\text { M: Pero iuy! si descubría su camisa recién } & \text { M: But gee! if he found his just laundered } \\
\text { lavada con olor a sudor... } & \text { shirt smelling of sweat... }\end{array}$ \\
\hline CDA & $\begin{array}{l}\text { She will suffer a negative consequence if her son finds out that she did not do well her job. } \\
\text { According to the name of the advertisement (Evita el drama - Avoid drama), it can be implied } \\
\text { that the negative consequence is drama. }\end{array}$ \\
\hline 4. & H: ¿La lavaste, mamá? $\quad$ S: Did you wash it, mom? \\
\hline CDA & $\begin{array}{l}\text { The son wants to make sure his mom has fulfilled her obligation, even when he seems } \\
\text { physically able to wash his own clothes. }\end{array}$ \\
\hline 5. & M: Sí! $\quad$ M: Yes! \\
\hline CDA & $\begin{array}{l}\text { The mother raises her tone of voice, in a way that lets the hearer know she obviously did her } \\
\text { job. }\end{array}$ \\
\hline 6. & H: iLa necesito ahorita! $\quad$ S: I need it now! \\
\hline CDA & $\begin{array}{l}\text { The son complains that his mother did not do her job on time as it is supposed to be. He } \\
\text { portrays a demanding and aggressive attitude, characteristics of a macho. Note. In the } \\
\text { functional grammar analysis, this utterance was taking as imperative because of what it } \\
\text { implies. }\end{array}$ \\
\hline 7. & H: iApesta! $\quad$ S: It stinks! \\
\hline CDA & $\begin{array}{l}\text { The son shows himself overbearing and emphasizes that his mom either did not do her job or } \\
\text { she not do it well. }\end{array}$ \\
\hline 8. & H: Y es de la suerte. \\
\hline CDA & He gives the shirt a high value. It is important. \\
\hline 9. & $\begin{array}{ll}\text { H: Con esta me ligaba a todas. } & \begin{array}{l}\text { S: With this [shirt], I used to tie all of them } \\
\text { [girls]. }\end{array}\end{array}$ \\
\hline CDA & He again demonstrates an attitude of Don Juan, like a macho. \\
\hline
\end{tabular}




\begin{tabular}{|c|c|}
\hline 10. & H: Ahora ninguna me va a pelar. $\quad$ S: Now, none is going to look at me. \\
\hline CDA & $\begin{array}{l}\text { However, this utterance means that he actually cannot conquer a girl by his own. He needs the } \\
\text { help of a clean and lucky shirt. }\end{array}$ \\
\hline 11. & $\begin{array}{l}\text { H: Me veo viviendo contigo hasta los } 40 \text { como } \\
\begin{array}{l}\text { el loco ese de los gatos. } \\
\text { like that crazy man of the cats. }\end{array}\end{array}$ \\
\hline CDA & $\begin{array}{l}\text { By means of this utterance, it can be implied that if his mother does not do well with the } \\
\text { laundry, he will not be able to 'tie a girl', consequently, he will not be able to become an } \\
\text { independent man. }\end{array}$ \\
\hline 12. & $\begin{array}{lc}\text { M: Estos dramones ya no me pasan desde } & \begin{array}{l}\text { M: These huge dramas do not happen to me } \\
\text { que probé Ariel. }\end{array} \\
\text { anymore since I tried Ariel. }\end{array}$ \\
\hline CDA & The mother assumes that using Ariel is the solution for not being mistreated by her own family. \\
\hline 13. & $\begin{array}{lc}\text { M: Con sus [del detergente] perlas saca } & \text { M: With its [the washing powder's] pearls, it } \\
\text { manchas difíciles y de sudor. } & \text { removes stubborn stains and sweat. }\end{array}$ \\
\hline CDA & This suggests that the advertised product is highly effective. \\
\hline 14. & M: He inherited the handsomeness of me. \\
\hline CDA & $\begin{array}{l}\text { The intention of this utterance could be, at the end of the day, saying something positive about } \\
\text { the mother. However, the center of attention is still the son. }\end{array}$ \\
\hline 15. & M: Ariel es poder. \\
\hline CDA & $\begin{array}{l}\text { Probably the purpose of this last utterance is to make the audience, in this case housewives, } \\
\text { feel empowered, by using the word "power", which in itself carries a great burden of meaning. } \\
\text { However, power is the least thing given to women in this advertisement. }\end{array}$ \\
\hline
\end{tabular}

Throughout the advertisement, it can be observable that the adolescent behaves as a macho and the woman is there to serve him, assuming the gender role that has been historically established by society.

\subsection{Visual semiotic analysis of the advertisement}

In this section, visual semiotics, meaning the visuals appearing during the advertisement, will be described and analyzed. The focus of attention will be the actions performed by the actors, including their gestures. I will analyze each of them separately. I will start with the name of the advertisement:

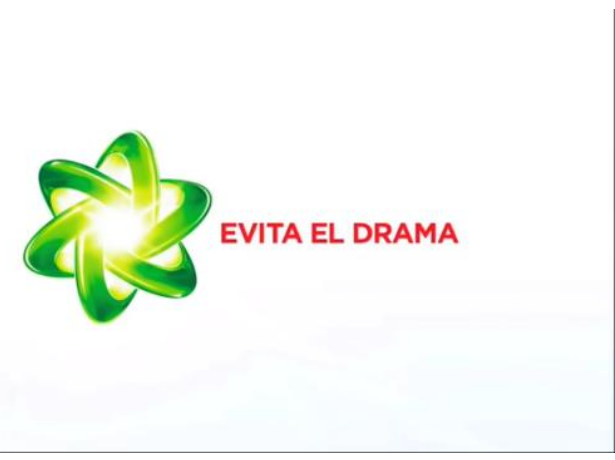

Note. The title of the advertisement. Source: Comerciales en Like México, “Ariel. Evita el drama”, 2018.

The title of the commercial is 'Evita el drama' (Avoid drama). Considering the whole advertisement, the meaning of the title could be interpreted as: "avoid to be mistreated. Do right your job!". 
The second feature to be analyzed is mother's role. I will describe and interpret her specific actions.

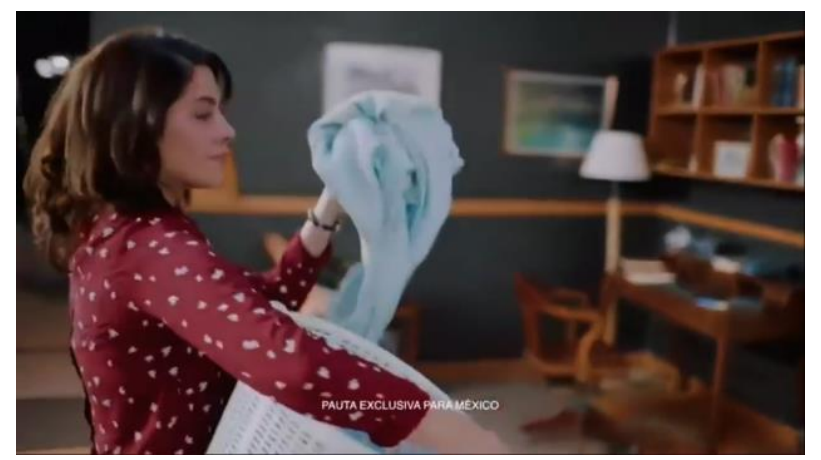

Note. Mother cleaning up the house. Source: Comerciales en Like México, “Ariel. Evita el drama”, 2018.

The advertisement takes place in a house of a middle-class family. The mother, a woman around her early 40's approximately:

- The mother does the domestic work.

- She picks up dirty laundry in what seems to be a study room.

- Then, she gets into the adolescent's bedroom to continue to pick the laundry up.

- When the adolescent starts speaking, the mother performs his speech, meaning that she already knows what is going to happen for not doing well her job, what reflects that this is a recurrent situation.

- Almost at the end of the advertisement, the mother fixes her son's shirt collar. This shows the adolescent's incompetency to do simple things as washing his clothes and reinforces the conception that who has to be behind her children's image is mom.

- Finally, the mother caresses her son's cheek, but he seems not to like it due to his facial expression, while she maintains a smile on her face. This gives the idea of a submissive mother, because it does not matter how bad the mother is treated, she will always be there with a smile on her face. In the end, it is a pleasure for her to be dedicated to the well-being of her family. Messages like this support the conception of the role of the mother as a domestic worker, while adds a meaning of enjoyment to that role.

The following feature is the adolescent's role. I will analyze his role, actions, gestures and attitudes.

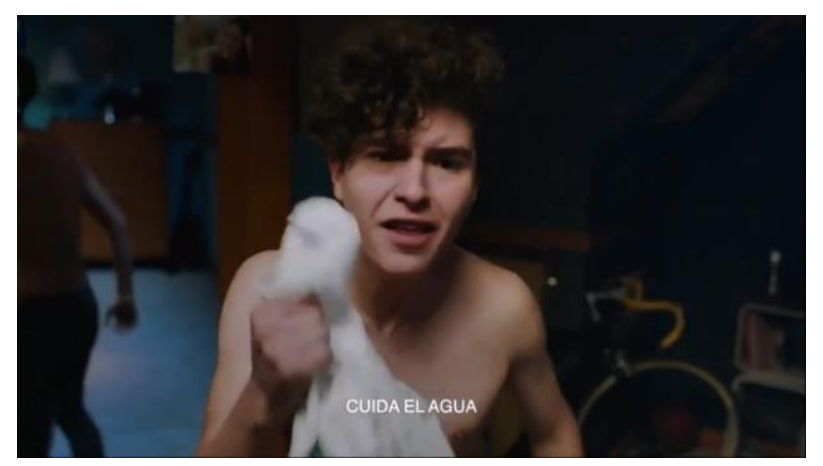

Note. Aggressive adolescent. Source: Comerciales en Like México, “Ariel. Evita el drama”, 2018. 
He is a male 17-year-old (approx.) adolescent:

- The moment he appears in the advertisement, he looks at himself in the mirror with a vain attitude, seen through his body-language.

- When he directs to his mother, he portrays an aggressive attitude. His body-language and gestures suggest confrontation. He frowns and his fists are clenched.

- He looks annoyed while his mom fixes his shirt collar.

- His last facial expression shows rejection, while his mom caresses his cheek. His attitude demonstrates a complete disrespect for his mother.

In summary, it could be concluded that this specific advertisement is publicity targeted to Mexican housewives belonging from low to middle-classes. Because thanks to the establishment of gender roles and the normalization of machismo in Mexican society groups, it is assumed that women are obliged to do the domestic work in their houses, without questioning this thought.

\section{Discussion}

In conclusion, bearing in mind that advertisements try to reflect the reality that a society would like to be part of, this advertisement reinforces gender roles and gender inequity by presenting the woman as the one in charge of domestic work. She is not only in charge of domestic work, but the other members of the family get annoyed if she does not do it or if she does it wrong. This, at the same time, contributes to the normalization of machismo and gender violence. Although there are some people who think that machismo does not shape a society to make it machista, but machismo is what shapes publicity; Ječmínková (2010) affirms that machismo in publicity influences machismo behaviors perpetuate in society. Therefore, the authorities should regulate the policies of publicity that are related to gender inequity and gender violence. Machismo and its normalization in publicity display two types of relations of power and dominance: power of men over women and the power of media over society.

\section{Conclusion}

This MDA was aimed to analyze a washing powder advertisement launched in Mexico in 2018. The analysis was made with two main sources. Halliday's functional grammar model was to analyze the meanings conveyed by means of the language use in the text. The text, the visuals and gestures were also analyzed having as a basis the principles of a CDA perspective. It was concluded that machismo and gender violence have been part of the Mexican lifestyle throughout history, that sometimes it is difficult to identify sexist publicity, which also affects the relations of power between men and women.

\section{Acknowledgements}

I would like to thank Dr. Troy Crawford Lewis for his support and encouragement in the publication of this article. I would also like to mention the support from Consejo Nacional de Ciencia y Tecnología (CONACYT).

This research did not receive any specific grant from funding agencies in the public commercial, or not-for-profit sectors.

The author declares no competing interests. 


\section{References}

Bignell, J. (1997). Media semiotics: An introduction. Manchester: Manchester University Press.

Blanco, E. (2005). Violencia de género y publicidad sexista. Chasqui. Revista Latinoamericana de Comunicación, 91, 50-55.

Campillo, F. (2000). El trabajo doméstico no remunerado en la economía. Nómadas (Col), (12), 98-115. Retreived from http://nomadas.ucentral.edu.co/nomadas/pdf/nomadas 12/12 10C Eltrabajodomesticono remunerado.pdf.

Comerciales en Like México (2018). ARIEL 'Evita el drama' (2018) [Video file]. Retrieved from https://www.youtube.com/watch?v=WVC3BvZzAKU.

Ewing, R. (2001). What is a functional model of language? Primary Teaching Association, 1-6. Retreived from https://www.petaa.edu.au/iMIS Prod/PETAA Docs/PPs-open/095F.pdf.

Expósito, F. (2011). Violencia de género. Mente y Cerebro, 48, $20-25$. https://www.uv.mx/cendhiu/files/2013/o8/Articulo-Violencia-de-genero.pdf.

Halliday, M. A. K. (1978). Language as social semiotic: The social interpretation of language and meaning . London: Edward Arnold.

Halliday, M. A. K., \& Matthiessen, C. (2004). An introduction to functional grammar ( $3^{\text {rd }}$ Ed.). London: Hodder Arnold.

Ječmínková, M. (2010). Análisis lingüístico de los anuncios publicitarios destinados a la mujer (1960-1970) [Unpublished bachelor dissertation]. Masarykova univerzita.

Kendon, A. (2013). Exploring the utterance roles of visible bodily action: A personal account. In C. Müller, A. Cienki, E. Fricke, S. Ladewig, D. McNeill \& S. Teßendorf (Eds.), Body - language communication: An international handbook on multimodality in human interaction (Vol. 1) (pp. 7-28). Berlin: De Gruyter Mouton.

Lewis, O. (1964). Los hijos de Sánchez. Autobiografía de una familia mexicana. Mexico City: Fondo de Cultura Económica.

Lugo, C. (1985). Machismo y violencia. Nueva Sociedad, 78, 40-47. Retreived from https://nuso.org/media/articles/downloads/1288 1.pdf.

Moral, J., \& Ramos, S. (2016). Machismo, victimización y perpetración en mujeres y hombres mexicanos. Estudios sobre las Culturas Contemporáneas, 22(43), 37-66. https://www.redalyc.org/pdf/316/31646035003.pdf.

Newman, L. K. (2002). Sex, gender and culture: Issues in the definition, assessment and treatment of gender identity disorder. Clinical Child Psychology and Psychiatry, 7(3), 352-359. https://doi.org/10.1177/1359104502007003004

Núñez, S. (2005). Género y televisión. Estereotipos y mecanismos de poder en el medio televisivo. Comunicar: Revista Científica Iberoamericana de Comunicación y Educación, 25(2). Retreived from https://dialnet.unirioja.es/servlet/articulo?codigo=2926137.

O’Halloran, K. L. (2011). Multimodal discourse analysis. In K. Hyland \& B. Paltridge (Eds.), The continuum companion to discourse analysis (pp. 120-136). London: Continuum International Publishing Group.

Paz, O. (2004). El laberinto de la soledad. Mexico City: Fondo de Cultura Económica. (Original work published 1950). 
L. Sánchez-Solís - Evita el Drama (Avoid Drama): A Multimodal Discourse Analysis...

Pedrero, M. (2004). Género, trabajo doméstico y extradoméstico en México. Una estimación del valor económico del trabajo doméstico. Estudios Demográficos y Urbanos, 19(2), 413-446. https://doi.org/10.24201/edu.v1gi2.1191

van Dijk, T. A. (1993). Principles of critical discourse analysis. Discourse \& Society, 4(2), 249-283. https://doi.org/10.1177/0957926593004002006

Van Leeuwen, T. (2015). Critical discourse analysis. The International Encyclopedia of Language and Social Interaction, 1-7. https://doi.org/10.1002/9781118611463/wbielsi174

Wodak, R. (2001). What CDA is about- a summary of its history, important concepts and its developments. In R. Wodak \& M. Meyer (Eds.), Methods of critical discourse analysis (pp. 1-13). London: Sage Publications. 